\title{
ATYPICAL PRESENTATION OF PRADER-WILLI SYNDROME WITH KLINEFELTER (XXY KARYOTYPE) AND CRANIOSYNOSTOSIS
}

\author{
Daniel R. Carvalho', Clovis S. Trad', João M. Pina-Neto \\ ABSTRACT - Prader-Willi syndrome is a mental retardation genetic disorder also characterized by hypog- \\ onadism, hyperphagia and obesity. We report on a four-years-old boy, born to consanguineous parents, \\ with uncommon co-occurrence of Prader-Willi syndrome, 47,XXY karyotype (Klinefelter syndrome) and \\ coronal craniosynostosis. These are different unrelated conditions and it was not described before in the \\ same patient to the best of our knowledge.
}

KEY WORDS: XXY karyotype, Prader-Willi syndrome, Klinefelter syndrome, craniosynostosis.

\begin{abstract}
Síndrome de Prader-Willi em paciente com Klinefelter (cariótipo XXY) e craniossinostose
RESUMO - A síndrome de Prader-Willi é afecção genética de deficiência mental associada a hipogonadismo hipogonadotrófico, hiperfagia e obesidade. Descrevemos o caso de menino de 4 anos de idade, filho de casal consangüíneo, apresentando três condições clínicas não relacionadas: síndrome de Prader-Willi, cariótipo 47,XXY (compatível com síndrome de Klinefelter) e craniossinostose coronal. Ao nosso conhecimento, não foi relatado caso semelhante previamente na literatura.
\end{abstract}

PALAVRAS-CHAVE: cariótipo XXY, síndrome de Prader-Willi, síndrome de Klinefelter, craniossinostose.

Prader-Willi syndrome (PWS) is a genetic disord er with prevalence of $1 / 10,000$ to $1 / 25,000$ characterized by hypotonia in early infancy, hyperfagia, obesity and mental retardation in childhood associated with hypogonadism and short stature ${ }^{1}$. Klinefelter synd rome (KS) is the most common sex chromosome disorder (1/500 male newborn) that usually is not easily clinical perceived during childhood and curses without developmental delay, but small testicles and infertility is a frequent problem in post-pubertal age ${ }^{2}$. Several patients with both PWS and KS have been documented. The last reports revealed distinct genetic mechanisms of the two conditions that reinforce the coincidental association of (1) uniparental maternal heterodisomy of chromosome 15 and paternal $X$ $Y$ chromosome non-disjunction ${ }^{3}$; or (2) paternally inherited microdeletion of chromosome 15 and maternal X-X inherited meiosis 1 non-disjunction ${ }^{4,5}$.

Butler et al. solicited more reports of affected PWS patients with atypical presentation ${ }^{3}$. We describe another case of this co-occurrence of PWS and KS with the additional aspect of coronal craniosynostosis.

\section{CASE}

We have evaluated a four-years-old boy since his first year of life. He is the second child of a young consanguineous couple $(\mathrm{F}=1 / 16)$ and his sister had an isolated cleft lip. He was born after an uneventful pregnancy and vaginal delivery with a birth weight of $2,566 \mathrm{~g}$ and birth length of $46 \mathrm{~cm}$.

At age 9 months, his length was $71 \mathrm{~cm}$ ( $25^{\text {th }}$ percentile), his weight was $7.8 \mathrm{~kg}$ ( $3^{\text {rd }}$ percentile), he had an OFC of 43.5 $\mathrm{cm}$ (between $3^{\text {rd }}$ and $10^{\text {th }}$ pe rcentile), hypotonia, brachycephaly with pronounced temporal bossing, small penis (length of $2.1 \mathrm{~cm}$, below $10^{\text {th }}$ percentile) and cryptorquidia with hypoplastic scrotum. Peripheral blood cytogenetic analysis (GTG) at 550 band level resolution showed a 47,XXY karyotype. Bonereconstruction CT scan revealed an early c l o su re of the anterior and posterior coronal sutures, but surgical intervention was not necessary (Figs 1, 2 and 3 ). Clinical observation noted obesity, hyperphagia and developmental delay without any sign of increased intracranial pressure. He sat at 18 months, crawled at 22 months and a broad-based flat-footed gait was observed at 3 years of age. At 4 years and $2 \mathrm{~m}$ onths of age, he had skin picking and was able to pronounce few words even after speech therapy. At this age, his length was $89 \mathrm{~cm}$ (below $3^{\text {rd }}$ per-

Hospital das Clínicas da Faculdade de Medicina de Ribeirão Preto da Universidade de São Paulo, Ribeirão Preto SP, Brazil: ${ }^{1}$ Médico Residente do Serviço de Genética Médica; ${ }^{2}$ Professor Responsável pelo Centro de Ciências das Imagens e Física Médica; ${ }^{3}$ Professor Associado do Departamento de Genética.

Received 3 March 2005, received in final form 18 October 2005. Accepted 17 November 2005. 


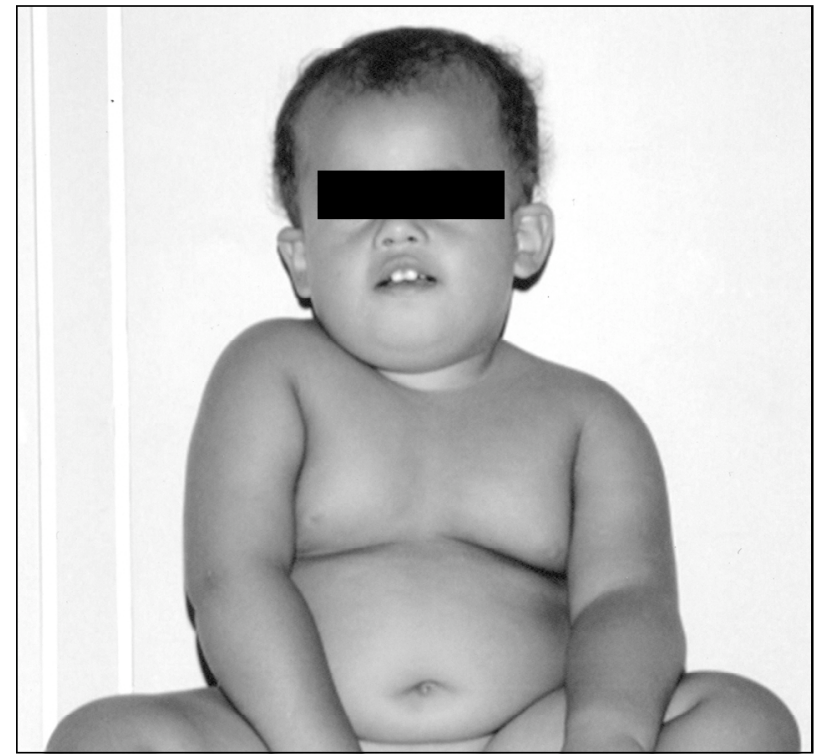

Fig 1. Frontal view of the propositus at 1 year and 9 months of age.

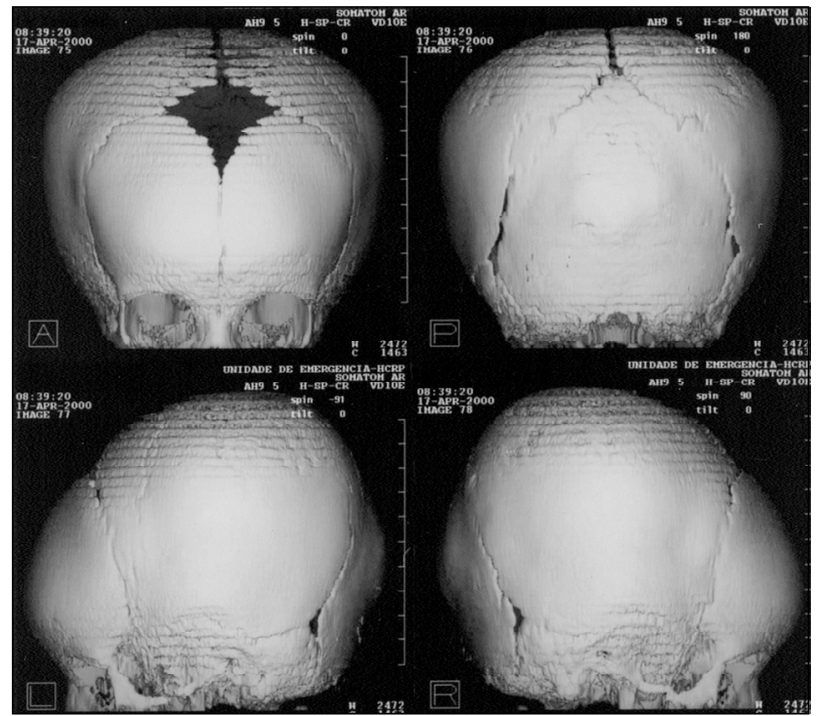

Fig 2. Bone reconstruction CT scan at 9 months of age show ing an early closure of the anterior and posterior coronal sutures.

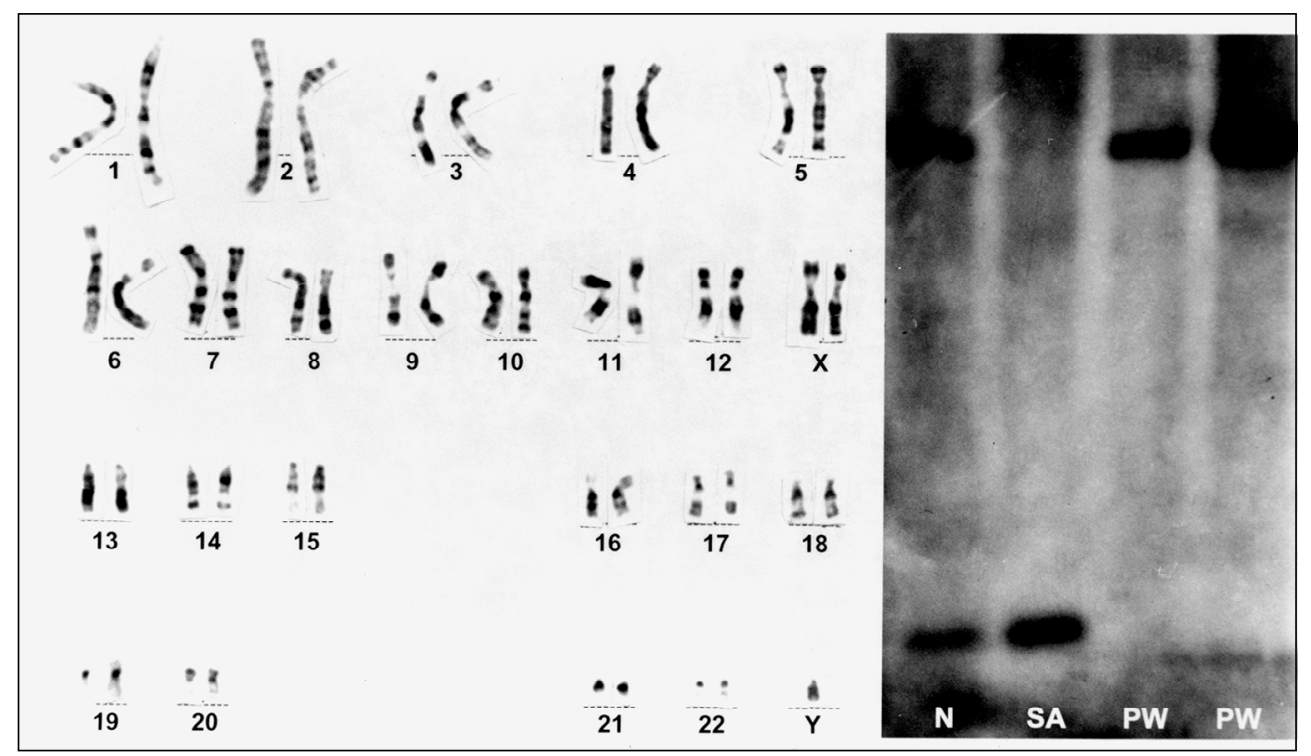

Fig 3. GTG banding karotype with 47 chromosomes and XXY. Picture of southern blotting methyla tion test of 15q11-13 region using a KB17 probe for exon 1 of SNRPN gene, after DNA digestion with $X b a I$ and NotI (methylation-sensitive restriction enzymes). $N$, normal pattern with a paternal derived $0.9 \mathrm{~kb}$ band and maternal derived $4.2 \mathrm{~kb}$ band; SA, pattern of Angelman syndrome with only a pater nal derived band; PW (left), pattern of Prader-Willi syndrome with only a maternal derived band; PW (right), patient sample which is compatible with Prader-Willi syndrome.

centile), his weight was $18 \mathrm{~kg}\left(75^{\text {th }}\right.$ percentile), and he had an OFC of $48.5 \mathrm{~cm}$ ( $3^{\text {rd }}$ pe rcentile). Also observed was a narrow bifrontal diameter, epicanthic folds, almond shaped oblique palpebral fissures, esotropia, cupid arch upper lip with sticky saliva, marked truncal obesity and small hands and feet.

A methylation analysis was done by Southern blotting using a KB17 probe to the $15 q 11-13$ region that confirmed the missing paternal $0.9 \mathrm{~Kb}$ band compatible with PWS ${ }^{1,6}$ (Fig 3). Unfort u n a te ly, his mother died in an accident before the last exam. His grandmother became his legal guardian because his father moved away. It was not possible to investigate the parental origin of the genetic abnomality mechanism. 


\section{DISCUSSION}

Craniosynostosis is considered a premature fusion of calvarial sutures, often associated with neuro l o gical manifestations or limb and craniofacial abnormalities. It can be an isolated clinical problem or part of diverse known syndromes ${ }^{7}$. The overall incidence for all forms of craniosynostosis is 1/2,000-1/2,500 live births?.

Considering the consanguinity and the absence of limbs anomalies, we propose that non-surgical prematurecoronal closure may be a recessive, nonsyndromic, form of craniosynostosis and also an incidental co-occurrence in this patient.

The clinical presentation of this case must be distinguished from non-synostotic posterior plagiocephaly (positional molding) secondary to hypotonia or sleeping in the supine position during the early perinatal period because anterior and posterior coronal sutures are involved bilaterally ${ }^{8}$.

Usually with the XXY boys, abnormalities are not a p p a rent during childhood, except for possible mild language delays. Additionally, some authors reported that small penis and testes, or underdevelopment of external genitalia, are possible clues to precocious detection of Klinefelter childre $n^{9}$, but these signs are found in few patients.

We believe that any uncommon aspect in XXY children - like hypotonia, hyperphagia, or the hypog- onadism detected in our patient - should raise suspicion for evaluation of another associated condition. It would promote the early diagnosis that is essential for adequate management of PWS children.

Our report reinforces the importance of following affected children with any genetic disorder. The co-occunence of these three unrelated different clinical problems in the same patient was not reported before.

\section{REFERENCES}

1. Pina-Neto JM, Ferraz VE, de Molfetta GA, Buxton J, Richards S, Malcolm S. Clinical-neurologic, cytogenetic and molecular aspects of the Prader-Willi and Angelman syndromes. A rq Neuropsiquiatr 1997;55: 199-208.

2. Smyth CM, Bremner WJ. Klinefelter syndrome. A rch Intern Med 1998;158:1309-1314.

3. Butler MG, Hedges LK, Rogan PK, Seip JR, Cassidy SB, Moeschler JB. Klinefelter and trisomy $\mathrm{X}$ syndromes in patients with Prader-Willi syndrome and uniparental maternal disomy of chromosome 15: a coincidence? Am J Med Genet 1997;72:111-114.

4. Geff roy S, Evrard V, Taufour D, Vanderbecken S, de Martinville B. Further example of a patient with Prader-Willi and Klinefelter synd romes of different parental origins. Am J Med Genet 1998;80:286-287.

5. Nowaczyk MJ, Zeesman S, Kam A, Taylor SA, Carter RF, Whelan DT. Boy with 47,XXY,del(15)(q112q13) karyotype and Prader-Willi synd rome: a new case and review of the literature. Am J Med Genet 2004; 125A:73-76.

6. Glenn CC, Saitoh S, Jong MT, et al. Gene structu re,DNA methylation, and imprinted expression of the human SNRPN gene. Am J Hum Genet. 1996;58:335-346.

7. Cohen MM Jr., MacLean RE. Craniosynostosis: diagnosis, evaluation and management, $2^{\text {nd }}$ edition. New York: Oxford University Press, 2000.

8. Ellenbogen RG, Gruss JS, Cunningham ML. Update on craniofacial su rgery: the differential diagnosis of lambdoid synostosis/ posterior plagiocephaly. Clin Neurosurg 2000;47:303-318.

9. Caldweel PD, Smith DW. The XXY (Klinefelter's) syndrome in childhood: detection and treatment. J Pediatr 1972; 80:250-258. 